\title{
ANTIFUNGAL TEST OF THE ETHANOL EXTRACT OF BROTOWALI STEM (Tinospora crispa) ON THE GROWTH OF Trichophyton rubrum IN VITRO
}

\author{
Nurul Nadifa Erza'), Fajriati Zulfa'), Yuni Setyaningsih²) \\ 1)Faculty of Medicine, Universitas Pembangunan Nasional 'Veteran' Jakarta \\ 2) Department of Parasitology, Faculty of Medicine, \\ Universitas Pembangunan Nasional 'Veteran' Jakarta
}

\begin{abstract}
Background: Trichophyton rubrum is an infectious dermatophyte fungus which is the most common cause of dermatophytosis. Fungal resistance and the side effects of therapy are problems of antifungal agents. Phytochemical test of brotowali stem extract (Tinospora crispa) consist of flavonoids, phenols and triterpenoids which have antifungal effects. This study aimed to examine the effectiveness of brotowali stem extract (Tinospora crispa) as antifungal agent towards the growth of Trichophyton rubrum in vitro using agar well diffusion method.

Subjects and Method: This was an experimental study using brotowali stem extract with concentration of $10 \%, 12,5 \%, 25 \%, 30 \%, 40 \%, 50 \%, 60 \%, 75 \%$, and $100 \%$. The dependent variable was Trichophyton rubrum growth. The independent variable was brotowali stem extract (Tinospora crispa). The data were obtained from the inhibition zone showed in agar well diffusion method in Sabouraud Dextrose Agar media. The data were analyzed using KruskalWallis test.

Results: The average diameter of inhibition zone of each variance (10\%, 12,5\%, 25\%, 30\%, 40\%, $50 \%, 60 \%, 75 \%$, and $100 \%$ ) were $2.167 \mathrm{~mm}, 6.367 \mathrm{~mm}, 7.0 \mathrm{~mm}, 10.67 \mathrm{~mm}, 119 \mathrm{~mm}, 13.07 \mathrm{~mm}$, $15.8 \mathrm{~mm}, 17.96 \mathrm{~mm}$ dan $17.13 \mathrm{~mm}$, respectively, and they were statistically significant $(\mathrm{p}=0.001)$. Conclusion: Brotowali stem extract has weak antifungal effectiveness at concentration 10\%, $12,5 \%, 25 \%$, intermediate antifungal effectiveness at concentration $30 \%$ and strong antifungal effectiveness at concentration $40 \%, 50 \%, 60 \%, 75 \%$ and $100 \%$.
\end{abstract}

Keywords: antifungal, brotowali stem, well diffusion, Trichophyton rubrum

\section{Correspondence:}

Fajriati Zulfa. Faculty of Medicine, Universitas Pembangunan Nasional ‘Veteran’ Jakarta. Jl. RS Fatmawati, Pondok Labu, Jakarta Selatan 12450, Telp. (o21) 7656971. Email: nurulnerza@gmail.com

The $7^{\text {th }}$ International Conference on Public Health Solo, Indonesia, November 18-19, 2020 370 https://doi.org/10.26911/the7thicph.05.02 